Bangladesh J. Bot. 43(2): 157-161, 2014 (September)

\title{
EPIZOOPHYTE COMPOSITION ON SPOTTED TURTLE EMYS ORBICULARIS (LINNAEUS, 1758) IN TURKEY
}

\author{
Elif Tezel Ersanli* and Arif Gonulol ${ }^{1}$ \\ Department of Biology, Faculty of Arts and Science, Sinop University, 57000, Sinop, Turkey
}

Key words: Epizoic algae, Bay, Delta, Lagoon

\begin{abstract}
A total of 59 species of epizoic algae were recorded from the carapace of Emys orbicularis (Linnaeus, 1758) (Testudinata, Emydidae). Division wise distribution of the recorded algae were Cyanophyta 26, Chlorophyta 13, Euglenophyta 5 and Chrysophyta 15. Among the recorded species Phormidium ambiguum, Pseudanabaena limnetica, Chroococcus spp. and Microcystis spp. were observed intensively.
\end{abstract}

\section{Introduction}

The preference for certain animal substrata of some benthic algae is one of the oldest subjects in freshwater phycology. Edgreen et al. (1953) suggested that epizoic community is a reciprocal evolution between the animals and the algae and is also a symbiotic relationship in which algae may benefit through simple motility and the turtle may provide camuflage. Epizoic algae take advantage of the animal substrata by increased access to light and nutrients associated with animal movement that would reduce the boundary zone thickness for nutrient intake, which would also potentially be increased by access to animal excreta, leachates, and secretions. The effects of epizoic algae on larger host animals such as snails and turtles are not known; they may help to camouflage the animals from predators or prey (Stevenson et al. 1996).

Epizoic or epizoophytic algae are usually collected from larger aquatic animals such as snails, clams and turtles. Study on this unique community of algae on turtles are very few (Edgreen $e t$ al. 1953, Neil and Allen 1954, Belusz and Reed 1969, Ernst and Norris 1978, Garbary et al. 2007). Therefore, further investigation on it and their relationship with the turtles need to be evaluated by the phycologists and herpetologists.

\section{Materials and Methods}

Epizoic algae from the carapace of Emys orbicularis (Linnaeus, 1758) (Testudinata, Emydidae) were collected from four locations of Turkey between May and August 2010. A brief description of the studied locations has been presented in Table 1. A total of 32 male and 23 female turtles were sampled.

Epizophytes were removed by brushing from the carapaces. The removed masses of algae were preserved in $4 \%$ formalin and examined and identified under Leica DM500 model microscope (Leica microsystems, Switzerland). The frequency of occurrence of phytoplankton species in these four areas were calculated by using the absence and presence and it was expressed as \%. Species identifications were based on Komárek and Anagnostidis (1986, 1999), Anagnostidis and Komárek (1988), Krammer and Lange-Bertalot, (1991a,b and 1999a,b) and John et al. (2003).

\footnotetext{
*Author for correspondence: <eersanli@sinop.edu.tr>. ${ }^{1}$ Department of Biology, Faculty of Arts and Science, Ondokuz Mayis University, 55139, Kurupelit Samsun, Turkey.
} 
Table 1. Description latitudes and longitudes (GPS) of the localities studied.

\begin{tabular}{lll}
\hline & Name and description of the locality & GPS \\
\hline 1. & Saros Bay, Canakkale, north eastern part of Aegean sea & $40^{\circ} 05^{\prime} \mathrm{N}$ and $26^{\circ} 33^{\prime} \mathrm{E}$ \\
2. & Sarikum Lagoon, Sinop, northernmost of Turkey, located in the & $42^{\circ} 01^{\prime} \mathrm{N}$ and $34^{\circ} 93^{\prime} \mathrm{E}$ \\
& National Park & \\
3. & Kizilirmak Delta, wetland area, Samsun & $41^{\circ} 20^{\prime} \mathrm{N}$ and $35^{\circ} 30^{\prime} \mathrm{E}$ \\
4. & Yesilirmak Delta, wetland area east of Samsun & $41^{\circ} 06^{\prime} \mathrm{N}$ and $36^{\circ} 23^{\prime} \mathrm{E}$ \\
\hline
\end{tabular}

\section{Results and Discussion}

Fifty-nine taxa were found on Emys orbicularis, including representatives of Cyanophyta (26), Chlorophyta (13), Euglenophyta (5) and Chrysophyta (15). The list of identified algae are given in Table 2.

Chroococcus pallidus and Geitlerinema acutissimum have been recorded from all the four areas. The frequency of Chroococcopsis fluviatilis, Lepocinclis oxyuris, Microcystis flosaquae, Phormidium ambiguum and P. terebriforme were 75\%. Amphora ovalis, Chroococcus minor, Gloeocystis vesiculosa, Jaaginema minimum, Lemmermanniella pallida, Lyngbya aestuarii, Oscillatoria limosa and Spirulina subsalsa had a frequency value of 50\%.

Chroococcus pallidus, Chroococcopsis fluviatilis, Geitlerinema acutissimum, Lepocinclis oxyuris, Microcystis flosaquae and Phormidium ambiguum showed wide ecological tolerance and were recorded in more than two areas. Amphora ovalis, Lyngbya aestuarii, Oscillatoria limosa and Spirulina subsalsa were seen in Kizilirmak and Sarikum (Table 2). Jaaginema minimum and Lemmermanniella pallida were recorded from Kizilirmak and Sarikum. In Saros Bay, the recorded epizophytes were Aphanocapsa elachista, Echinosphaerella limnetica, Klebsormidium mucosum and Trachelomonas sp.. Cymatopleura solea var. subconstricta, Gongrosira debaryana, Spirogyra jugalis and Synedra ulna were distrubuted in Yesilirmak Delta.

It was seen that a small population of algae had been colonized on the carapace of turtles which were collected in the Saros Bay. However, extensive population was seen on the carapace of turtles from the lagoon and deltas. The reason for this, is that deltas have shallow lakes, these lakes are connected to each other and turtles move between these channels. Sarikum Lagoon is shallow and has a large littoral region which is suitable for the survival of turtles. Therefore, for the colonization of epizophytes, habitat type is more important than turtle genera. In this study, it was seen that some filamentous and colonial algae e.g., Phormidium ambiguum, Pseudanabaena limnetica and Chroococcus spp. and Microcystis spp. were characteristic to shallow eutrophic lakes.

Soylu et al. (2006) recorded Chroococcus dispersus, Hantzschia amphioxys, Microcystis aeruginosa, Pseudanabaena limnetica, Rhoicosphenia abbreviata, Scenedesmus obliquus and Synedra ulna on E. orbicularis. These algae except, the other algae in Table 2 which is determined in this study are the first record as epizoic on the E. orbicularis in Turkey. Belusz and Reed (1969) reported Gongrosira debaryana from painted turtle, (Chrysemys picta Schneider 1783) and map turtle (Graptemys geographica Lesueur 1817). Also Homoeothrix juliana, Meridion circulare and Oscillatoria limosa were reported as epizoic on skin surface of fishes (Shin et al. 2004).

There have been several studies on the epizoic algae on turtles but little information is found in the literature. The two algae namely, Dermatophyton and Basicladia are common on turtles (Edgreen et al. 1953, Belusz and Reed 1969, Ernst and Norris 1978, Colt et al. 1995, Garbary et al. 2007). Epizoic freshwater algae on E. orbicularis were investigated and fifty-three algal taxa were found on thirty five turtles (Soylu et al. 2006). 
Table 2. Epizoic algae found on turtles carapace in the study areas.

\begin{tabular}{|c|c|c|c|c|}
\hline Taxa & Sarikum & Saros & Yesilirmak & Kizilirmak \\
\hline \multicolumn{5}{|l|}{ Cyanophyta } \\
\hline Aphanocapsa elachista West \& G.S. West & - & + & - & - \\
\hline Chroococcus dispersus (Keissler) Lemmermann & + & - & - & - \\
\hline C. minimus (Keissler) Lemmermann & + & - & - & - \\
\hline C. minor (Kützing) Nägeli & + & + & - & - \\
\hline C. pallidus Nägeli & + & + & + & + \\
\hline C. turgidus (Kützing) Nägeli & - & - & - & + \\
\hline C. fluviatilis (Lagerheim) Komárek \& Anagnostidis & + & - & + & + \\
\hline $\begin{array}{l}\text { Dolichospermum affine (Lemmermann) P. Wacklin, L. } \\
\text { Hoffmann \& J. Komárek }\end{array}$ & + & - & - & - \\
\hline Geitlerinema acutissimum (Kufferath) Anagnostidis & + & + & + & + \\
\hline Gomphosphaeria aponina Kützing & + & - & - & - \\
\hline Homoeothrix juliana (Meneghini) Kirchner & + & - & - & - \\
\hline Hydrococcus rivularis Kützing & + & - & - & - \\
\hline Jaaginema minimum (Gicklhorn) Anagnostidis \& Komárek & - & + & - & + \\
\hline Lemmermanniella pallida (Lemmermann) Geitler & - & + & - & + \\
\hline Leptolyngbya aeruginea (Kützing ex Hansgirg) Komárek & + & - & - & - \\
\hline Lyngbya aestuarii Liebman ex Gomont & + & - & - & + \\
\hline Microcystis aeruginosa (Kützing) Kützing & + & - & - & - \\
\hline M. flosaquae (Wittrock) Kirchner & + & - & + & + \\
\hline Oscillatoria limosa C. Agardh ex Gomont & + & - & - & + \\
\hline Phormidium ambiguum Gomont & + & - & + & + \\
\hline $\begin{array}{l}\text { P. terebriforme (C. Agardh ex Gomont) Anagnostidis \& } \\
\text { Komárek }\end{array}$ & + & + & + & - \\
\hline $\begin{array}{l}\text { Planktothrix rubescens (De Candolle ex Gomont) } \\
\text { Anagnostidis \& Komárek }\end{array}$ & + & - & - & - \\
\hline Pseudanabaena limnetica (Lemmermann) Komárek & + & - & - & - \\
\hline P. mucicola (Naumann \& Huber-Pestalozzi) Schwabe & + & - & - & - \\
\hline Spirulina subsalsa Oerstedt ex Gomont & + & - & - & + \\
\hline Tolypothrix tenuis Kützing & + & - & - & - \\
\hline \multicolumn{5}{|l|}{ Chlorophyta } \\
\hline Klebsormidium mucosum (Boye Petersen) Lokhorst & - & + & - & - \\
\hline Spirogyra jugalis (Dillwyn) Kützing & - & - & + & - \\
\hline S. longata (Vaucher) Kützing & - & - & - & + \\
\hline S. lutetiana Petit & - & - & - & + \\
\hline Desmodesmus opoliensis (P.G. Richter) E.H. Hegewald & - & - & - & + \\
\hline Echinosphaerella limnetica G.M. Smith & - & + & - & - \\
\hline Gloeocystis vesiculosa Nägeli & + & + & - & - \\
\hline
\end{tabular}




\section{(Contd.)}

\begin{tabular}{|c|c|c|c|c|}
\hline Gongrosira debaryana Rabenhorst & - & - & + & - \\
\hline Scenedesmus bijuga (Turpin) Lagerheim & + & - & - & - \\
\hline S. ellipticus Corda & + & - & - & - \\
\hline S. obliquus (Turpin) Kützing & - & - & - & + \\
\hline S. quadricauda (Turpin) Brébisson & - & - & - & + \\
\hline Westellopsis linearis (G.M. Smith) C.C. Jao & + & - & - & - \\
\hline \multicolumn{5}{|l|}{ Euglenophyta } \\
\hline Euglena pisciformis Klebs & - & - & - & + \\
\hline Lepocinclis oxyuris (Schmarda) Marin \& Melkonian & + & + & - & + \\
\hline L. steinii Lemmermann & - & - & - & + \\
\hline Menoidium pellucidum Perty & - & - & - & + \\
\hline Trachelomonas sp. & - & + & - & - \\
\hline \multicolumn{5}{|l|}{ Chrysophyta } \\
\hline Amphora ovalis (Kützing) Kützing & + & - & - & + \\
\hline A. commutata Grunow & - & - & - & + \\
\hline Caloneis silicula (Ehrenberg) Cleve & - & - & - & + \\
\hline Chaetoceros sp. & + & - & - & - \\
\hline Cyclotella sp. & - & - & - & + \\
\hline Cymatopleura solea var. subconstricta O. Müller & - & - & + & - \\
\hline Gyrosigma acuminatum (Kützing) Rabenhorst & + & - & - & - \\
\hline Hantzschia amphioxys (Ehrenberg) Grunow & - & - & - & + \\
\hline Melosira lineata (Dillwyn) C. Agardh & + & - & - & - \\
\hline Meridion circulare (Greville) C. Agardh & - & - & - & + \\
\hline Navicula sp. & + & - & - & - \\
\hline Nitzschia longissima (Brébisson) Ralfs in Pritchard & + & - & - & - \\
\hline Rhoicosphenia abbreviata (C. Agardh) Lange-Bertalot & + & - & - & - \\
\hline Rhopalodia gibba (Ehrenberg) Otto Müller & - & - & - & + \\
\hline Synedra ulna (Nitzsch) Ehrenberg & - & - & + & - \\
\hline
\end{tabular}

Edgreen et al. (1953) stated that certain species of turtles seem to be heavily epizoophytized whereas certain others support little or no algae. This situation is explained on the basis of random distribition of algae on the various turtle species and Emys are frequently epizoophytized. Investigators have suggested many reasons for the epizoophytes. Edgreen et al. (1953) thought that the alga-turtle relationship was best defined as commensalism, whereas Neil and Allen (1954) expressed that, a little epizoic growth along the seams of the carapace serves to break up the reptile's outlines, and suggests an inanimate object rather than a living creature. Algae are transported from one place to another, and thus they are spread. Turtles may provide an additional disseminating agent for the epicolous species. Shedding of the scutes in late summer and fall appared to be main factor controlling algal colonization (Belusz and Reed 1969). 


\section{Acknowledgements}

Sincere thanks are due to Yunus Emre Dincaslan (Director of the Special Environmental Protection Regions, Izmir), Murat Tosunoglu, Associate Professor, Department of Biology, Canakkale Onsekiz Mart University and Dudu Bal Ozbek (Academic Writing Center) for their help to carry out the research.

\section{References}

Anagnostidis K and Komárek J 1988. Modern approach to the classification system of Cyanophytes. 3 Oscillatoriales. Arch. Für Hyd. 80: 327- 472.

Belusz LC and Reed RJ 1969. Some Epizoophytes on six turtle species collected in Massachusetts and Michigan. Amer. Mid. Nat. 81: 598-601.

Colt LC, Saumure RA and Baskinger S 1995. First record of the algal genus Basicladia (Chlorophyta, Cladophorales) in Canada. The Can. Field-Nat. 109: 454-455.

Edgreen RA, Edgreen MK and Tiffany LH 1953. Some North American turtles and their epizoophytic algae. Eco. 34: 733-740.

Ernst CH and Norris JN 1978. Observations on the algal genus Basicladia and the red bellied turtle, Chrysemys rubriventris. Estu. 1: 54-57.

Garbary DJ, Bourque G, Herman TB and McNeil JA 2007. Epizoic algae from freshwater turtles in Nova Scotia. J. Fresh. Eco. 22: 677-685.

John DM, Whitton BA and Brook AJ 2003. The freshwater algal flora of the British Isles: An Identification Guide to Freshwater and Terrestrial Algae. The Natural History Museum and The British Phycological Society. Cambridge University Press.

Komárek J and Anagnostidis K 1986. Modern approach to the classification system of Cyanophytes 2-Chroococcales. Arch. Für Hyd. 73: 157-226.

Komárek J and Anagnostidis K 1999. Cyanoprokaryota, Chroococcales, Süßwasserflora Von Mitteleuropa. Gustav Fisher Verlag. 19: 54.

Krammer K and Lange-Bertalot H 1991a. Süßwasserflora von Mitteleuropa. Bacillariophyceae, Band 2/3, 3. Teil: Centrales, Fragillariaceae, Eunoticeae. Gustav Fischer Verlag. pp. 1-576.

Krammer K and Lange-Bertalot H 1991b. Süßwasserflora von Mitteleuropa. Bacillariophyceae, Band 2/4, 4. Teil: Achnanthaceae. Kritische Ergänzungen zu Navicula (Lineolatae) und Gomphonema Gesamtliteraturverzeichnis. Gustav Fischer Verlag. pp. 1-436.

Krammer K and Lange-Bertalot H 1999a. Süßwasserflora von Mitteleuropa. Bacillariophyceae, Band 2/1, 1. Teil: Naviculaceae. Spectrum Academicher Verlag Heidelberg. pp. 1-876.

Krammer K and Lange-Bertalot H 1999b. Süßwasserflora von Mitteleuropa. Bacillariophyceae, Band 2/2, 2. Teil: Bacillariaceae, Epithemiaceae, Surirellaceae. Spectrum Academicher Verlag Heidelberg. pp. 1-610.

Neil WT and Allen ER 1954. Algae on turtles: Some additional considerations. Eco. 35: 581-584.

Shin JK, Seo J, Yi HS, Jeong SA and Hwang SJ 2004. Ecological studies of epizoic algae attached on the freshwater, Fishes in a Small Stream (Ian Stream), South Korea, Kor. J. Lim. 37: 462-467.

Soylu EN, Gönülol A, Sukatar A, Ayaz D and Tok CV 2006. Epizoik freshwater algae on Emys orbicularis (Testudinata: Emydidae) from the central Anatolia Region of Turkey. J. Fresh. Eco. 21: 535-538.

Stevenson RJ, Bothwell ML and Lowe RL 1996. Algal Ecology: Freshwater benthice ecosystems. Academic Press, San Diego.

(Manuscript received on 24 July, 2013; revised on 10 December, 2013) 